\title{
Congenital agminated melanocytic nevus - Case report ${ }^{*}$
} Nevo melanocítico congênito agminado - Relato de caso

\author{
Camila Roos Mariano da Rocha ${ }^{1}$ \\ Laura Luzzatto ${ }^{3}$
}

\author{
Thaís Corsetti Grazziotin² \\ Renan Rangel Bonamigo ${ }^{4}$
}

Maria Carolina Widholzer Rey²

DOI: http://dx.doi.org/10.1590/abd1806-4841.20132137

\begin{abstract}
Agminated nevus is a cluster group of melanocytic nevi confined to a localized area of the body. There are many pigmented lesions described in the literature as agminated, such as blue nevi, multiple lentigines and Spitz nevi, but only a few cases of congenital agminated melanocytic nevi have been described. We report a case of a male child who presented with congenital agminated nevi, emphasizing the importance of physical examination, dermoscopy, histopathological evaluation, differential diagnosis and follow up to rule out the possibility of dysplastic or malignant changes.

Keywords: Clusterin; Nevus; Nevus, intradermal; Nevus, Pigmented; Skin and Connective Tissue Diseases

Resumo: Nevo agminado é um conjunto de lesões melanocíticas confinadas a uma área do corpo. Existem muitas lesões descritas na literatura como agminadas, como nevos azuis, lentigos múltiplos, nevo de Spitz, mas existem poucos casos de nevos melanocíticos agminados congênitos descritos. Relatamos o caso de um paciente do sexo masculino que se apresentou com um nevo agminado congênito, enfatizando a importância do exame físico, dermatoscopia, avaliação histológica, diagnóstico diferencial e seguimento para descartar a possibilidade de alterações displásicas ou malignas.

Palavras-chave: Clusterina; Doenças da Pele e do Tecido Conjuntivo; Nevo; Nevo intradérmico; Nevo pigmentado
\end{abstract}

\section{INTRODUCTION}

Agminated nevi are infrequent pigmented lesions. 'Agminated' is derived from the Latin word 'agmen', meaning 'aggregation' and refers to a clustered or circumscribed grouping of lesions confined to a localized area of the body. It should be distinguished from other forms of segmental distribution lacking a definite clustering. ${ }^{1}$

Pigmented lesions that have been described in the literature as agminated include blue nevi, multiple lentigines, Spitz nevi, congenital melanocytic nevi, acquired melanocytic nevi, and lesions within nevi spili. ${ }^{2-5}$ No hyperpigmented lesions described as agminated include xanthogranuloma, angiofibromas and neurilemomas. ${ }^{6}$

Most cases reported in the literature corresponded to Spitz or blue nevi, with only few descriptions of melanocytic congenital agminated nevi. Only a few cases of congenital agminated melanocytic nevi have been described in literature., ${ }^{4,7}$ One of these cases presented with a "blaschkoid" pattern following Blaschko lines on the abdomen. ${ }^{8}$

The main differential diagnosis is nevus spilus. This nevus commonly appears during late infancy or early childhood, leading to the belief that they are a type of congenital nevus. ${ }^{3,6}$ A tan lentiginous background patch on which more darkly pigmented macules and papules are distributed characterizes the lesion. The nevus spillus usually presents as lentigo simplex on the histological analysis whereas agminated nevus generally shows a junctional or compound melanocytic nevus. ${ }^{9}$

The association of melanoma with agminated nevus was initially described by Marghoob et al, in a patient with atypical mole syndrome, a pre-existent

\footnotetext{
Received on 17.09.2012.

Approved by the Advisory Board and accepted for publication on 07.11.2012.

* Work performed at the Dermatology Service of the Health Sciences Federal University of Porto Alegre (UFCSPA) - Porto Alegre (RS), Brazil. Conflict of interest: None

Financial funding: None

Medical resident of Dermatology at Hospital Federal da Lagoa - Rio de Janeiro (RJ), Brazil.

MD, Dermatologist. Masters in Pathology. Universidade Federal de Ciências da Saúde de Porto Alegre (UFCSPA) - Porto Alegre (RS), Brazil

MD, Pathologist - Dermatology Service at Universidade Federal de Ciências da Saúde de Porto Alegre (UFCSPA) - Porto Alegre (RS), Brazil.

MD, PhD, Head of Dermatology Service at Universidade Federal de Ciências da Saúde de Porto Alegre (UFCSPA) - Porto Alegre (RS), Brazil. 
melanoma and a dysplastic agminated nevus on the arm that first appeared during puberty. ${ }^{6}$ Later were described two cases of melanoma arising directly from agminated melanocytic lesions. The first one, published by Corradin et al, described the development of an invasive melanoma in an acquired agminated nevus that appeared after thermal and solar burn. ${ }^{9}$ Most recently Rezze et al reported the case of a patient affected by atypical mole syndrome and with personal history of melanoma who presented an agminated nevus on the anterior chest since puberty. ${ }^{10}$ Some nevi within the agminated lesion presented clinical and dermoscopic criteria of atypic nevus. The whole lesion was excised and the histopathological analysis showed an in situ melanoma, some areas of severe dysplasia and other areas corresponding to junctional, intradermal and compound nevi.

\section{CASE REPORT}

A nine-year-old male patient, phototype $\mathrm{V}$, student, was referred to the dermatology clinic for evaluation of multiple pigmented lesions on his left thigh. He was accompanied by his father, who informed that the child had had a cluster of melanocytic lesions since birth. The cluster increased in size following the growth of the patient and the minor lesions became somewhat closer together over the years. The family background of skin cancer was negative. The father has a history of congenital nevi on the face and left lumbar region. The patient presented epilepsy and was in treatment with carbamazepine, imipramine and risperidone.

On physical examination, the patient had a cluster of approximately 20 maculopapular, lightly palpable blackened lesions of different sizes on the anterior part of his left thigh, forming a cluster of nevi (Figures 1 and 2). The diameter of the total lesion was $9.2 \mathrm{~cm} \times 7.6 \mathrm{~cm}$. The largest isolated lesion measured $2.6 \mathrm{~cm} \times 1.3 \mathrm{~cm}$. Dermoscopy revealed predominantly homogeneous pattern with diffuse brownish areas, regular network at the periphery and numerous regularly distributed small dots (Figure 3). No background pigmentation was noted on clinical or dermoscopic examination between lesions.

A single lesion was excised for histological evaluation with a $2 \mathrm{~mm}$ border of normal skin. The histopathological findings revealed an intradermal melanocytic nevus without histological melanocytic hyperplasia or hyperpigmentation in clinically normal peripheral skin (Figures 4 and 5).

Considering the clinical and histopathological diagnosis of the lesion and treatment limitations due to the size of the total lesion, it was decided to keep dermoscopic monitoring of the patient every 4 months. It has enhanced to the family the importance of sun protection and guidance for the observation of changes such as modification of color, palpation (such as nodularity), shape and rapid growth.

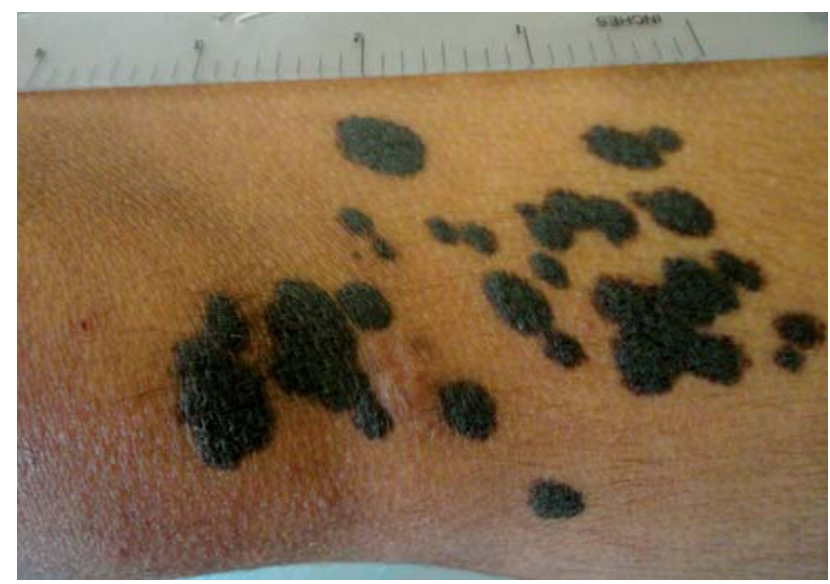

FIGURE 1: Multiple pigmented lesions on the left thigh

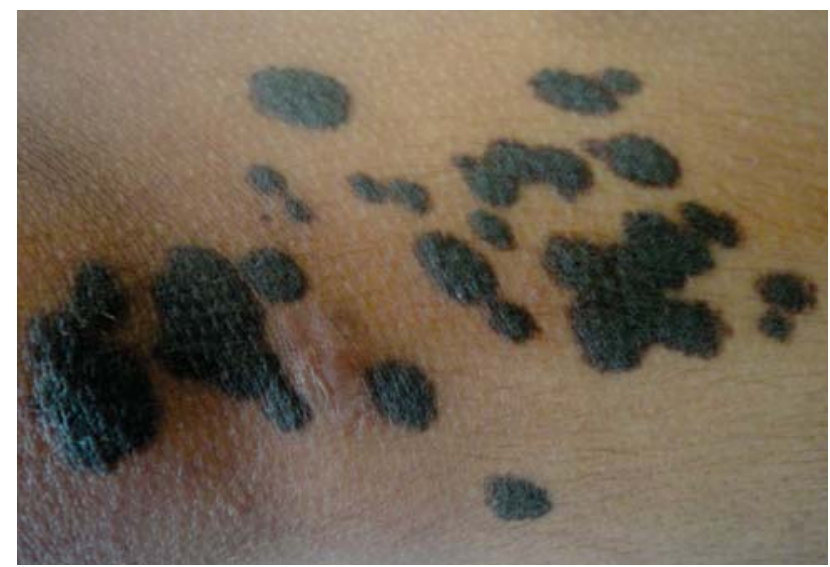

FIGURE 2: Detail of the melanocytic lesions within the area of biopsy

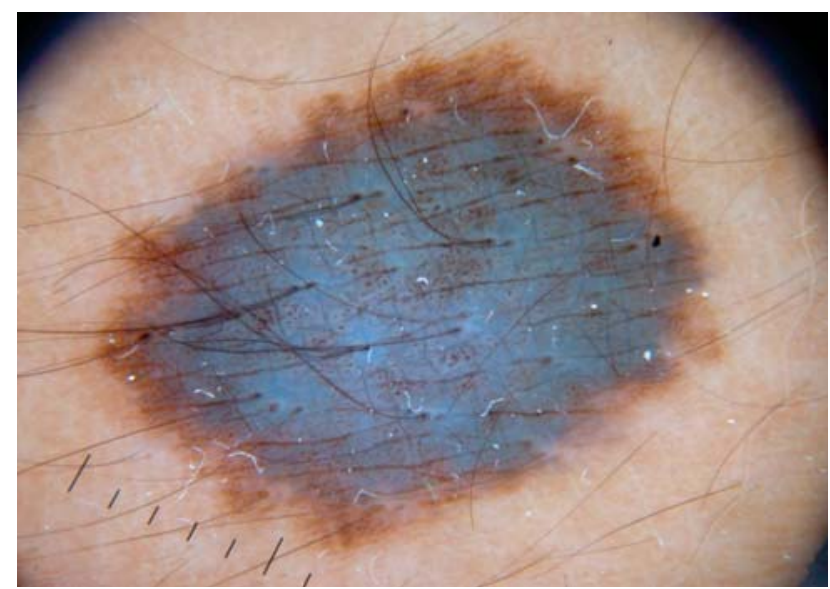

FigURE 3: Dermoscopy revealed predominantly homogeneous pattern with diffuse brownish areas, regular network at the periphery and numerous regularly distributed small dots 


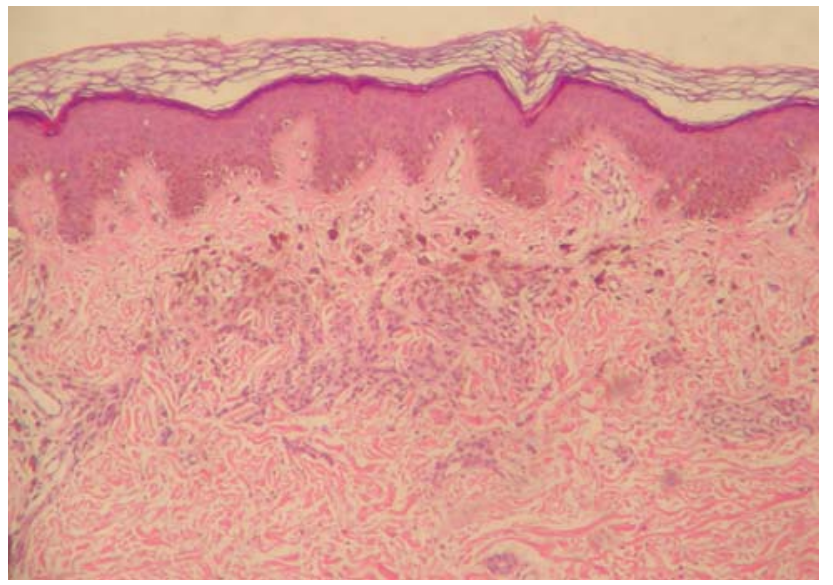

FIGURE 4: Histopathology revealed intradermal melanocytic nevus without melanocytic hyperplasia in the peripheral skin between the nevi

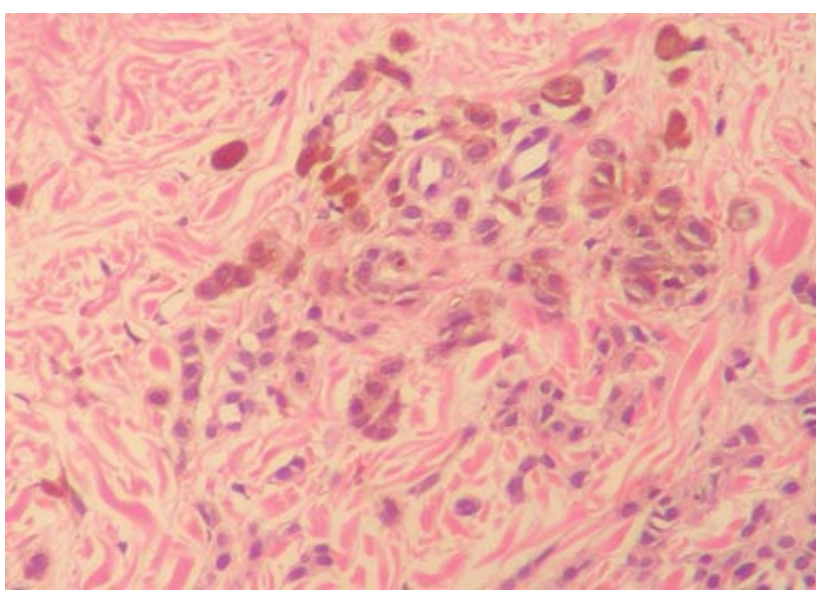

FIGURE 5: A higher magnification reveals nevus cell nests along the papillary dermis

\section{DISCUSSION}

Agminated nevus is a rare lesion and its incidence is unknown. In this case the patient has a congenital agminated nevus, a rare condition.

The patient presented a cluster of melanocytic lesions in the anterior part of the left thigh. There were no dysplastic or malignant changes on clinical examination, dermoscopy or histology. It can be differentiated from nevus Spillus by the absence of brown macular background in the clinical examination and histopathology.

The association between epilepsy and agminated melanocytic nevus is to the best of our knowledge not found in the literature. There is an established relationship between big and giant congenital melanocytic nevi with neurocutaneous melanosis, in which the occurrence of epilepsy is common. In this case there was no suspicion of indication for investigation for cutaneous melanosis.

The decision to follow or excise this particular and rare presentation of compound nevus should be individualized. We decided to monitor the patient since the lesion was large and without atypical clinical, dermoscopic and histological findings. Long-term follow-up is recommended due to the possibility of malignant transformation, even if this probability is at the moment not exactly defined.]

\section{REFERENCES}

1. Happle R. Segmental lesions are not always agminated. Arch Dermatol. 2002;138:838.

2. Micali G, Nasca MR, Innocenzi D, Lembo D. Agminated lentiginosis: case report and review of the literature. Pediatr Dermatol. 1994;11:241-5.

3. Menni S, Betti R, Boccardi D, Gualandri L. Both unilateral naevus achromicus and congenital agminated Spitz naevi in a checkerboard mosaic pattern. Br J Dermatol. 2001;144:187-8.

4. Brunner M, Vardarman E, Megahed M, Ruzicka T. Congenital agminated segmental naevi. Br J Dermatol. 1995;133:315-6.

5. Betti R, Inselvini E, Palvarini M, Crosti C. Agminated intradermal Spitz nevi arising on an unusual speckled lentiginous nevus with localized lentiginosis: a continuum? Am J Dermatopathol. 1997:19:524-7.

6. Marghoob AA, Blum R, Nossa R, Busam KJ, Sachs D, Halpern A. Agminated atypical (dysplastic) nevi: case report and review of the literature. Arch Dermatol. 2001;137:917-20

7. Martín JM, Pinazo MI, Monteagudo C, García L, Jordá E. Congenital agminated nevi on the trunk. Int J Dermatol. 2003;42:942-3.

8. Cabanillas Gonzáles M, Monteagudo B, de las Heras C, Cacharrón JM. Unilateral agminated melanocytic nevi. Dermatology. 2009;218:387-8.

9. Corradin MT, Alaibac M, Fortina AB. A case of malignant melanoma arising from an acquired melanocytic naevus. Acta Derm Venereol. 2007;87:432-3.

10. Rezze GG, Leon A, Silva DC, Neves RI, Molina GC, Carraro DM, et al. Primary cutaneous melanoma arising in agminated melanocytic nevi: CDKN2A and CDK4 mutation screening. Acta Derm Venereol. 2012;92:98-9.

\author{
MAILING ADDRESS: \\ Thaís Corsetti Grazziotin \\ Rua Sarmento Leite, 245 \\ 90050-170 - Porto Alegre - RS \\ Brazil \\ E-mail:tcgrazziotin@gmail.com
}

How to cite this article: Rocha CRM, Grazziotin TC, Rey MCW, Luzzatto L, Bonamigo RR. Congenital agminated melanocytic nevus: case report. An Bras Dermatol. 2013;88(6 Suppl 1):S170-2. 